\title{
Sosialisasi Strategi Menarik Minat Konsumen Untuk Membeli Produk Hasil UMKM
}

\author{
Dede Suleman ${ }^{1}$, Sabil ${ }^{2}$, Ida Zuniarti ${ }^{3}$, Sri Rusiyati ${ }^{4}$ \\ ${ }^{1,2}$ Program Studi Manajemen, Fakultas Ekonomi Dan Bisnis, Universitas Bina Sarana Informatika, \\ Jakarta, Indonesia. \\ ${ }^{3,4}$ Program Studi Manajemen, Fakultas Ekonomi Dan Bisnis, Universitas Nusa Mandiri, Jakarta, \\ Indonesia. \\ Email: ${ }^{1}$ dede.dln@bsi.ac.id, ${ }^{2}$ sabil.sbl@bsi.ac.id, ${ }^{3}$ ida.idz@nusamandiri.ac.id, ${ }^{4}$ sri.siq@nusamandiri.ac.id
}

\begin{abstract}
This activity aims to provide knowledge about the importance of understanding consumers in this new era because in the sales process in the era and the COVID-19 pandemic, consumer behavior will definitely change. Therefore, the activity with the theme "Strategy to attract consumers to buy UMKM products" is expected to be a solution for UMKM in which the material presented includes the characteristics of consumers and also how to techniques to make consumers feel like buying products produced by UMKM. it is still difficult to be able to market the products they produce and this affects the income level of UMKM actors. At the end of these community service activities, we evaluate by giving questionnaires with respondents to see the percentage of participants' satisfaction levels during community service activities and to measure quantitatively the percentage of influence and impact after completing the implementation of service activities Some of the strategies shared in this socialization are new methods that UMKM actors can use to adapt in the marketing era $n$ new. And it is hoped that it can change the mindset of UMKM actors in making the right marketing strategy in order to increase sales.
\end{abstract}

Keywords: Marketing Strategy, Consumer Behavior, Sales

\begin{abstract}
Abstrak
Dalam Kegiatan ini bertujuan untuk memberikan pengetahuan akan pentingnya memahami konsumen diera baru ini karena dalam proses penjualan diera dan pandemic covid 19 perilaku konsumen pasti akan berubah. oleh karena itu kegiatan yang bertema "Strategi menarik minat konsumen untuk membeli produk UMKM " diharapkan bisa menjadi solusi bagi UMKM yang mana materi yang disampaikan meliputi bagaimana karakteristik konsumen dan juga bagaimana teknik untuk membuat konsumen merasa ingin membeli produk yang dihasilkan UMKM. Karena banyak pelaku UMKM masih kesulitan untuk bisa memasarkan produk yang mereka hasilkan dan ini menjadi berpengaruh terhadap tingkat pendapatan para pelaku UMKM. Di akhir kegiatan pengabdian masyarakat tersebut kami melakukan evaluasi dengan cara memberikan koesioner dengan responden orang untuk melihat presentase tingkat kepuasan peserta selama mengikuti kegiatan pengabdian masyarakat serta untuk mengukur secara kuantitatif presentase pengaruh dan dampak yang ditimbulkan setelah selesai mengikuti pelaksanaan kegiatan pengabdian. Beberapa strategi yang dibagikan dalam sosialisasi ini adalah metode baru yang bisa digunakan pelaku UMKM untuk beradaptasi di era pemasaran baru. Dan diharapkan bisa merubah pola pikir para pelaku UMKM dalam membuat strategi pemasaran yang tepat agar bisa meningkatkan penjualan.
\end{abstract}

Kata Kunci: Strategi Pemasaran, Perilaku Konsumen, Penjualan

\section{A. PENDAhuluan}

Pandemi Covid-19 sudah lebih dari satu tahun melanda semua negara di dunia termasuk Indonesia. Banyak perubahan terjadi dalam berbagai sektor kehidupan manusia untuk beradaptasi dalam menghadapi pandemi Covid-19. Bagi perusahaan, bisa bertahan pada saat dan setelah pandemi Covid-19 bukan karena besar dan kuat tetapi seberapa cepat perusahaan tersebut mampu merespon untuk beradaptasi dengan mengadopsi cara baru dalam proses bisnisnya. Bagi pelaku usaha, harus fleksibel dalam menghadapi dan menyesuaikan diri terhadap semua situasi dan kondisi di lingkungan yang baru atau "New Normal"(Kartajaya \& Marketeers, 2018). 
Pelaku usaha perlu melakukan inovasi untuk bisa dapat bersaing dan tetap bertahan di new era atau era digital saat ini (Kotler et al., 2019), hadirnya teknologi informasi saat ini juga sudah menjadi sebuah kebutuhan yang sangat berarti di berbagai sendi kehidupan (Suleman, 2018). Teknologi akan membantu pelaku usaha dalam berinteraksi dengan konsumen secara cepat dan tepat, relevansi serta jangkauan yang tidak terbatas dalam kondisi apapun melalui semua perangkat teknologi secara real time.

Konsumen yang beragam membuat kita perlu belajar untuk membuat strategi agar bisa menarik (Suleman et al., 2020a). Dalam kondisi krisis dan setelah krisis di masa pandemi Covid-19 terjadi perubahan perilaku dan ekspektasi konsumen. Adanya Pembatasan Sosial Berskala Besar (PSBB) tidak memungkinkan untuk berkumpul atau melakukan aktifitas di luar rumah. Hal ini menyebabkan perubahan perilaku belanja pada konsumen, berpindah ke online, artinya konsumen tidak ingin membuang waktu yang lama baik proses pembelian maupun menunggu produk yang dibeli (Suleman et al., 2020b)

Seperti yang kita tahu bahwa konsumen era ini lebih banyak ragam dan jenisnya yang membuat pelaku UMKM harus bisa beradaptasi dengan perilaku konsumen saat ini. Perilaku konsumen berbeda didasari oleh berbagai macam stimulus yang mendasarinya (Sumawan, 2002) . Sehingga upaya baru terus dilakukan untuk bangkit di era normal ini terus digalakkan, untuk bisa terus bertahan, bisa menciptakan lapangan pekerjaan yang banyak dan bisa menjadi sumbangsih pemasukan daerah dari produk yang dihasilkan oleh UMKM.

Peran semua pihak tentu turut bisa membantu tujuan bersama yaitu membangkitkan perekonomian di daerah pada akhirnya berdampak pada pertumbuhan perekonomian secara nasional. Terutama di era baru ini konsumen sudah beradaptasi dengan cara baru dengan sebutan citizen 4.0 yang tentunya punya perilaku yang berbeda pula dari perilaku yang sebelumya (Suleman et al., 2021). Ini yang menjadi tantangan yang dihadapi oleh para pelaku UMKM Naik kelas untuk bisa memasarkan produk mereka di era yang baru ini.

Strategi menarik minat konsumen di masa "New Normal" untuk komunitas UMKM, adalah:

1. Fokus;

Pelaku UMKM harus fokus terhadap kualitas produk, strategi promosi, apa yang menjadi kebutuhan, keinginan dan permasalahan konsumen.

2. Unik;
Produk, promosi, metode pembayaran, layanan harus berbeda dengan competitor dan sesuai dengan keinginan dan kebutuhan konsumen.

3. Konsistensi;

Konsisten dalam kecepatan melaksanakan Fokus dan Unik dalam menarik hati konsumen untuk mempertahankan dan mendapatkan konsumen.

4. Ketahui konsumen;

Segmenting, Targeting, dan Positioning (STP) merupakan hal mendasar untuk mengetahui calon konsumen yang akan menjadi target pemasaran, selanjutnya yang perlu menjadi perhatian adalah keinginan, kebutuhan, dan daya beli serta perilaku konsumen tersebut.

Kegiatan Pengabdian Masyarakat ini bertujuan untuk mendorong peningkatan pengetahuan komunitas ini dengan memberikan pelatihan dengan tema" Strategi Menarik minat Konsumen Untuk Membeli Produk Hasil Komunitas UMKM". Peserta pelatihan ini adalah para pelaku UMKM yang tergabung dalam Komunitas UMKM Naik Kelas. Dengan informasi yang disampaikan kepada para pelaku UMKM melalui internet, maka UMKM akan dengan mudah menerima informasi baru dan mendapat wawasan melakukan strategi pemasaran yang tepat (Suleman et al., 2019). Dapat diambil kesimpulan bahwa produk yang mereka hasilkan sudah memiliki keunikan dan juga kualitas produk yang masih bisa diandalkan ini menjadi kunci keberhasilan yang bisa di expose sebagai produk yang bisa berdaya saing tinggi dengan produk-produk lain buatan luar negeri karena produk UMKM pada umumnya terinspirasi dari kearifan lokal para pendirinya

\section{B. PELAKSAAAN DAN METODE}

Dalam kegiatan ini cara pelaksanaan yang digunakan adalah untuk mengatasi permasalahan saat ini yang dihadapi oleh para pelaku UMKM yang mana diawali dengan melakukan observasi dan pemberian kuesioner kepada pelaku UMKM untuk menentukan presentase tingkat kesulitan dan tingkat kemudahan yang mereka alami dalam memasarkan produk dan jasa yang mereka hasilkan diera baru ini, dan nanti akan ada evaluasi sampai nanti idealnya dilakukan kegiatan lanjutan pada tahap membandingkan dengan data sebelum dan sesudah pelaksanaan kegiatan pelatihan stategi pemasaran yang baru ini.

Permasalahan prioritas yang dihadapi oleh UMKM antara lain mencakup hal-hal berikut ini.

1. Sulitnya mengakses memasarkan produk yang dihasilkan.

2. Pengetahuan pemahaman ragam konsumen dan perilakunya di era baru ini. 
3. Pemahaman cara membuat konsumen tertarik untuk membeli produk yang dihasilkan

Banyak pelaku UMKM yang mengalami kesulitan untuk bisa memasarkan produk yang mereka hasilkan sehingga ini menjadi titik perhatian yang perlu dicarikan solusinya karena memang tombak dari usaha adalah bagaimana bisa menjual produk kepada konsumen. Pemahaman perubahan era ini perlu diketahui oleh para pelaku UMKM naik kelas untuk bisa beradaptasi dan merubah strategi pemasaran yang digunakan selama ini. Mengingat era saat ini konsumen memiliki perilaku yang sedikit bergeser dalam rangka proses keputusan pembelian suatu produk. Upaya ini diharapkan bisa membantu para UMKM naik kelas untuk bisa membuat stategi yang baik agar konsumen mau membeli produk yang mereka hasilkan.

\section{HASIL DAN PEMBAHASAN}

Hampir selama satu tahun ini Indonesia dilanda dampak dari pandemi Covid 19 yang sangat begitu besar dirasakan oleh seluruh lapisan masyarakat diberbagai bidang. Peraturan pemerintah dalam menerapkan protokol kesehatan yaitu menjaga Jarak menyebabkan terputusnya informasi ilmu pengetahuan terutama dibidang pendidikan. Pelaku usaha perlu melakukan inovasi untuk bisa dapat bersaing dan tetap bertahan di new era atau era digital. Sehingga untuk mempercepat adaptasi pelaku usaha harus memainkan strategi pemasaran bisnisnya. Berikut cara-cara yang bisa digunakan pelaku usaha untuk sukses bertahan di tengah pandemi Covid-19 oleh karena ini paling tidak ada 6 strategi baru yang dapat dilakukan para pelaku usaha UMKM diera pemasaran 4.0 saat ini antarai lain :

\section{Berfikir dan Bertindak Cepat}

Berfikir cepat untuk meningkatkan value bukan hanya menawarkan produk yang diproduksi kepada konsumen. Tantangan ini menjadi perlu dilakukan ditengah persaingan di era baru yang mana butuh perhatian lebih jika ingin tetap bertahan atau bahkan maju beradaptasi pada masa digital dimana persaiangan sudah semakin menantang karena semua produsen menawarkan produk yang hampir sama kepada konsumen. Kecepatan pada semua proses baik itu pembelian, pemasaran serta produksi dan inovasi produk. Dari waktu ke waktu, dunia tempat di mana kita hidup terus mengalami kemajuan, namun kemajuan zaman yang kita alami tidak serta merta selalu berhasil membawa kita ke arah yang lebih baik. Salah satu efek yang ditimbulkan dari kemajuan zaman tersebut yaitu manusia cenderung menjadi makhluk yang konsumtif tanpa diimbangi dengan produktivitas yang sebenarnya bisa mereka lakukan. Kemudahan yang kita nikmati selama ini kadang membentuk pribadi seseorang yang malas dan tidak produktif. Kecepatan serta ketepatan dalam melakukan berbagai aktivitas hidup sangat penting untuk kita kuasai di era Millenial ini. Sebagian ada yang mampu mengepakkan sayapnya di dunia yang semakin hingar bingar ini, namun banyak pula diantara mereka yang belum menyadari dan belum bisa mengoptimalkan potensi berpikir cepat dan bertindak tepat dalam dirinya sehingga mereka seringkali kesulitan dalam menjalani hidup dan merasa jauh dari kesuksesan yang mereka inginkan.

Era ada dalam zona nyaman adalah sifat alami yang dimiliki manusia. Hal inilah yang kemudian menyebabkan kemampuan mental manusia cenderung kurang berkembang dan dimanfaatkan. Banyak orang yang malas berpikir, menghindari hal-hal yang kompleks dan sesuatu yang bersifat baru. Tayangan tv, pengaruh media sosial, kegagalan membaca dan belajar membuat seseorang tidak mampu berfungsi dengan cepat dan efisien.

Ini memberikan hal-hal baru yang dapat membuat pembaca berani menantang pikirannya untuk menjadi lebih kuat dan tangguh dalam membuat pilihan dan keputusan terbaik dengan serangkaian cara yang sederhana dan praktis. Dalam pembukaannya Brian menyebut rata-rata orang hanya menggunakan 2 persen kemampuan mentalnya, untuk bisa menjadikannya berfungsi optimal kita perlu melatihnya. Otak merupakan otot yang dapat diperkuat secara substansial dari waktu ke waktu, terutama ketika proses itu dikombinasi dengan istirahat yang cukup (setidaknya delapan dari 24 jam setiap hari), latihan fisik yang ketat, dan nutrisi yang tepat. Kita juga tahu bahwa sebagian besar batas manusia adalah pemaksaan diri dan banyak orang yang tersandera dalam ideologi kenyamanan dan tirani adat (kebiasaan lama). Jadi tidak perlu takut dengan IQ yang Anda miliki, kita bisa mendapatkan kecerdasan dengan melatihnya.

Ada tiga hal yang bisa kita lakukan untuk menjadi lebih cerdas yaitu : Pertama, melihat setiap hal secara utuh. Kita tidak tahu pasti berapa persen sel otak yang kita gunakan setiap harinya, tetapi kita harus berusaha menggunakannya seratus persen selama 24 jam sehari. Artinya kita harus bekerja maksimal setiap waktu sehingga ketika gagal kita masih lebih baik dibanding orang lain dan tidak akan bingung membuat keputusan selanjutnya. Kedua, meluangkan waktu untuk berfikir dan memahami tujuan. menganalogikan pikiran manusia seperti gelembung di gelas sampanyem, percikan itu segera hilang dan gelembung hanya berisi udara. Jadi yang kita perlukan adalah upaya sadar untuk mendapatkan masukan baru dari sistem cepat ke sistem lambat. Brian menyarankan agar 
kita meluangkan waktu untuk berfikir terutama jika berkaitan dengan tujuan jangka panjang. Ketiga, hindari pemikiran yang mekanis seperti mesin. Yang terpenting saat ini adalah bagaimana kita mampu berfikir kreatif. Coba kita lihat di sekitar kita, apakah ada restaurant yang menjual menu yang sama dalam lima belas tahun? Bukankah mereka bertahan karena kreativitas mereka membuat pilihan lain?

Saat ini, tidak ada yang selamanya berhasil, tetapi semuanya selalu bisa diperbaiki. Ada tiga langkah agar kita bisa terhindar dari pemikiran yang mekanis, yaitu dengan berfikir lebih jelas, lebih fokus, dan konsentrasi. Kita harus berani menetapkan tujuan, tetapi dengan cara yang mudah dan fleksibe. Kita juga harus menghabiskan waktu dengan efektif dan efisien. melakukan sesuatu dengan waktu yang lebih sedikit tetapi hasilnya lebih baik. Ada kalanya kita harus mematikan telepon dan menghindari email untuk membangun lingkungan dengan cara yang benar.

Orang yang sukses memiliki kebiasaan berpikir yang melintasi banyak pola, mereka melakukan tindakan dengan pemikiran besar yang sulit diterima. Mereka selalu menempatkan sebagian besar waktu dan energi mereka untuk mewujudkan sesuatu hal yang berharga dan menghilangkan kegiatan yang bernilai rendah. Mereka bertanggung jawab untuk diri mereka sendiri. Mereka berlatih berpikir dan bertindak dengan cara yang berkontribusi pada kesuksesan mereka sampai menjadi kebiasaan.

\section{Fleksibel}

Inovasi nyatanya penting dilakukan dalam berbisnis. Inovasi pun tak hanya sebatas produk. Lebih dari itu produsen harus bisa mengikuti perkembangan era dengan cepat. Perubahan ini bisa merubah konsep bisnis baik itu segi produk atau program pemasaran. Kekakuan produsen diera ini bisa membawa dampak buruk karena perilaku konsumen sendiri sudah berubah oleh era mau tidak mau kebutuhan baru terus tumbuh keinginan dilayani lebih juga meningkatkan upaya produsen dalam memasarkan produk yang mereka hasilkan. perubahan besar dalam fase kehidupan dan bagaimana cara berpikir terbaik yang paling mampu menyesuaikannya. Kita semua sebenarnya memiliki semua yang dibutuhkan untuk berpikir fleksibel/elastis. Bahkan lebih dari yang kita sangka. Sebenarnya memanfaatkannya hanya soal menyadari keahlian yang dibutuhkan dan mengembangkannya.

Pikiran sudah sejak lama telah melebihi kemampuan pemrosesan informasi komputer dan harusnya terus seperti itu. Bentuk pemikiran itu adalah pemikiran yang orisinil, non-linear dan bersudut pandang general maupun spesifik sesuai kondisinya. Pikiran logis memungkinkan kita untuk berkendara dari rumah ke pasar melalui jalur yang paling efisien, tapi pemikiran fleksibel lah yang memungkinkan kita untuk menjalaninya secara otomatis. Berpikir fleksibel adalah kemampuan untuk mengabaikan hal-hal kecil yang tidak penting dan menelurkan ide-ide gila. Otak manusia tidak bekerja dengan memproses satu macam informasi dalam sekali jalan, tapi berbagai informasi bersamaan yang berkompetisi dan saling berinteraksi satu sama lain. Makanya banyak ahli yang menyinggung soal sadar/gak sadar, alasan logis/emosi ataupun otak kanan/otak kiri saat berbicara soal berpikir fleksibel. Struktur tersebut bersinggungan dengan struktur-struktur lainnya yang berebut ruang di pikiranmu.

Kamu pasti gak jarang mendengar orang berbicara, "aku memang begini orangnya", "karakter itu susah diubah", atau "aku sudah dari dulu seperti ini”. Memang secara sekilas itu menunjukkan bahwa mereka enggan berpikir atau bertindak fleksibel dan lebih memilih berada dalam karakter zona nyaman mereka. Namun tidak banyak kok orang yang seperti itu. Karena di era modern ini, bertindak dan berpikir fleksibel sangat dibutuhkan untuk bisa sukses. Para ahli menyebut karakteristik fleksibel yang dinikmati dengan nama "neophilia". Mereka bersedia untuk berubah menjadi lebih baik dan belajar hal baru. Salah satu kemampuan lain yang akan mendukungmu dalam berpikir fleksibel adalah kemampuanmu untuk menenangkan pikiranmu sendiri atau kemampuan untuk "pasrah" dengan berbagai masukan. Fokus itu memang diperlukan untuk berpikir rasional/logis, tapi itu berarti akan membuat pikiranmu dipenuhi dinding-dinding yang memfilter informasi masuk. Pemikiranmu akan menjadi tidak kreatif dan tidak fleksibel. Sebaliknya jika pikiranmu tenang, segala inspirasi akan masuk dan ide bisa muncul bertubi-tubi dengan pengolahan informasi yang baik. Jadi sangat penting ketika kamu berpikir tentang suatu masalah dengan sangat intens, kamu memberikan jeda untuk melakukan aktivitas ringan yang kamu cintai. Dengan begitu, kamu tetap bisa berpikir logis/rasional tapi diikuti pemikiran kreatif dan terbuka. Kamu sendiri merasa lebih sering berpikir logis atau fleksibel?

\section{Agility}

Banyak yang menyebut bahwa UMKM memiliki tingkat ketahanan tinggi ketika menghadapi krisis, dibandingkan usaha besar. Ya para pelaku UMKM bisa lincah dalam perubahan sebuah usaha yang masih kecil sangat memungkinkan perubahan drastic yang cepat dilakukan tanpa procedure yang ketat ini merupakan salah satu kelebihan yang bisa dipakai diera ini. Dalam arti harfiah, agile dapat berarti tangkas, lincah, atau gesit. Bisnis yang agile 
adalah bisnis yang dapat beradaptasi dengan cepat pada dinamika pasar, merespon dengan tepat dan fleksibel pada permintaan pelanggan. Selain itu perusahaan dapat beradaptasi dan mengawali perubahan dengan cara yang produktif dan hemat biaya tanpa mengorbankan kualitas, serta terus menjadi perusahaan yang kompetitif.

Beberapa langkah berikut dapat menciptakan sebuah perusahaan yang agile:

a. Pendelegasian Langkah pertama untuk menciptakan agility dalam fungsi bisnis adalah dengan mendelegasikan kontrol operasional pada karyawan frontline dan melatih mereka secara berkelanjutan sehingga mereka bisa melakukan pekerjaan dengan baik.

b. Menentukan tujuan Dari pada menjelaskan semua perubahan dan meminta semua orang untuk mengikutinya, berikan arahan dan visi serta biarkan tim anda mewujudkan visi tersebut menjadi realita.

c. Pelibatan karyawan Setelah tujuan ditentukan, anda perlu orang untuk terlibat dalam program tersebut yang bisa berubah dan membuat perubahan.

d. Pengalokasian sumber daya Untuk membangun agility, pikirkan dalam-dalam bagaimana mengalokasikan sumber daya ke bagian-bagian dalam bisnis yang penting untuk menciptakan agility dengan tepat.

e. Mengukur progress Penting untuk secara berkelanjutan mengukur dan memonitor progres tim anda. Sebuah aspirasi yang jelas untuk dicapai membuat pengukuran dan pemantauan progres menjadi lebih mudah.

f. Penghargaan Apa yang memberikan imbalan akan dikerjakan. Penting untuk menghubungkan akuntabilitas dengan kesuksesan atau kegagalan sebuah proyek. Agar hal itu terjadi, tim anda perlu tahu apa yang diharapkan dari mereka.

Sebuah bisnis agility yang sukses membutuhkan aspirasi, keterlibatan, alokasi sumber daya, pengukuran progres, dan penghargaan. Menyatukan semua faktor ini dapat meningkatkan agility dalam perusahaan. Manfaat yang bisa didapatkan dengan menciptakan agility dalam perusahaan antara lain:

a. Penyederhanaan tugas Proses kerja yang agile membantu menyederhanakan pekerjaan dan menghemat energi karena memprioritaskan tugas-tugas penting dan meminimalkan langkah untuk mencapainya.

b. Tim yang multidisipliner Salah satu manfaat terbesar dari bekerja dengan agile adalah berbagi pengetahuan. Keseimbangan yang baik antara pengetahuan teknis dan hubungan yang baik meningkatkan kualitas perusahaan dan efektivitas dalam bekerja.

c. Menambah nilai dan mengurangi limbah Agility membuat waktu pengerjaan dan anggaran proyek menjadi lebih pasti dan spesifik dan tim anda bisa berkonsentrasi pada kualitas.

d. Membantu organisasi berinovasi Organisasi yang sukses kepemimpinannya melibatkan karyawan untuk berinovasi dan mengembangkan ide-ide baru. Proses inovasi pada agility melibatkan komunikasi yang baik pada tujuan jangka panjang.

e. Membangun ketahanan Dengan menantang karyawan untuk menjadi lebih agile dalam mengambil tindakan dan mengekspresikan ide dengan tanggung jawab dan kontrol, anda bisa meningkatkan tidak hanya individu namun juga ketahanan seluruh organisasi.

\section{Teknologi}

Memilih untuk beradaptasi dan bertransformasi dari operasional bisnis offline ke online adalah pilihan yang tepat. Dengan membuat jurnal online, semua penagihan dan pembayaran dapat dilakukan dengan mudah, tanpa harus bertatap muka. Dokumen penagihan atau pembayaran dari pelanggan, bisa dicek langsung lewat banyak jaringan, seperti email atau WhatsApp. Dengan menggunakan jurnal online, maka cashflow pun tetap terjaga.

Perkembangan teknologi merupakan sesuatu yang tidak bisa kita hindari dalam kehidupan sekarang karena dengan kemajuan teknologi akan berjalan sesuai dengan kemajuan ilmu pengetahuan. Secara keseluruhan manusia tidak lepas dari adanya sebuah teknologi karena teknologi merupakan cara mudah dalam setiap kegiatan manusia terutama teknolgi sangat membantu manusia mendapatkan kebutuhan dan keinginan mereka secara instant. Dalam menumbuhan kebutuhan dan keinginan manusia secara modern, sebuah teknologi juga membutuhkan pemasaran untuk mengatur seluruh aspek merencanakan, menentukan harga, mempromosikan dan mendistribusikan barang dan jasa yang memuaskan kebutuhan baik kepada pembeli yang ada maupun pembeli yang potensial jadi, disini teknologi dan pemasaran sebagai hal yang dapat dikaitkan sebagai pola yang saling menguntukan, jika tidak ada teknologi maka pemasaran akan menjadi terbelakang dan tidak akan maju untuk memenuhi tuntutan zaman .

Teknologi informasi merupakan tulang punggung pada manajemen supply chain karena konsep supply chain tidak bisa dipisahkan dari perkembangan teknologi informasi. Pada konsep supply chain semakin banyak perusahaan yang terlibat dalam rantai tersebut, maka akan semakin 
kompleks strategi pengelolaan yang perlu untuk dibangun. Dalam konteks pemasaran, internet sangat membawa dampak transpornasional yang menciptakan paradigma baru dalam berbisnis yaitu berupa digital marketing, istilah ini mengacu pada sebuah proses dalam perusahaan terlibat aktivitas bisnis yang dilakukan secara elektronik atau yang biasa disebut dengan e-commerce. E-commerce memiliki beberapa perbedaan jika dibandingkan dengan bisnis tradisional.

Pada konsep tradisional commerce pembeli dan penjual akan bertemu dan berinteraksi secara langsung di pasar atau di toko sedangkan dalam konsep e-commerce penjual dan pembelii tidak bertemu secara langsung melainkan pertemuan kedua belah pihak di jembatani sebuah website tempat kedua belah pihak akan melakukan transaksi. Dengan adanya pemanfaatan internet dan teknologi sebagai media promosi dan pasar dapat membuat kebutuhan dan keinginan manusia terpenuhi. Teknologi yang terkoneksi dengan jaringan internet global memberikan peluang dalam pemasaran produk dan jasa. Dengan jaringan internet, website design quality yang menarik merupakan suatu alat promosi yang baik dan lebih murah terutama dalam bisnis jasa. Pengaruh teknologi dalam e-commerce membuat penyampaian informasi secara cepat. Jika zaman dulu, dalam memasarkan produk harus menunggu beberapa minggu baru tersampaikan. Tetapi dengan kemajuan sekarang para penjual maupun pembeli tidak perlu menunggu lama karena dapat diakses melalui sebuat jaringan internet maupun situs-situs terkait. Selain itu, dengan adanya e-commerce konsumen merasa nyaman saat bertransaksi karena tidak perlu antri karena terbantu dengan adanya mobile banking.

Dampak yang kurang baik bagi teknologi dibidang pemasaran adalah adanya kesenjangan social. Dalam kaitannya dengan pertumbuhan ekonomi dan ketidaksamaan pemerataan peranan teknologi yang sangat besar, karena perkembangan teknologi berkaitan erat dengan stratifikasi social. Dalam hal ini surplus ekonomi dalam kaitannya dengan pemasaran dianggap berkaitan dengan perkembangan teknologi, jadi penetapan ekonomi rendah maupun pendapatan ekonomi tinggi sangat berdampak terhadap kesenjangan social. Disamping itu teknologi mungkin menjadi revolusioner karena peran teknologi dalam masyarakat namun teknologi merupakan salah satu factor yang dapat mengubah tatanan suatu masyarakat.

Teknologi telah membuat perubahan bentuk maupun kapasitas sehingga menghilangkan ciri khas personal dalam sebuah produk. Penggunaan teknologi baru menuntut penyesuaian struktur social budaya dengan cepat. Akibatnya, masyarakat tersebut akan mengalami suatu kondisi kritis yang dapat berujung pada sebuah kelompok atau kesatuan baru. Teknologi dalam pemasaran mempunyai peran penting untuk meningkatkan eksistensi sebuah perusahaan atau suatu badan usaha. Pemasaran pada zaman sekarang ini, jika tidak ditunjang dengan adanya perkembangan teknologi yang maju tidak mungkin dapat dipasarkan secara maksimal. Peranan teknologi dalam pemasaran yakni menunjang kegiatan-kegiatan yang saling berhubungan sehingga pemasaran barang dan jasa dapat berjalan secara maksimal.

\section{Empati}

Para pelaku UMKM yang berhasil berdiri di tengah pandemi ini karena mereka mengatur atau merencanakan anggaran dengan matang. Pelaku usaha saat ini harus melihat dari sisi konsumen yang mana konsumen juga memiliki banyak masalahnya sendiri dari hal ini harus dipahami oleh pemasar saat ini. Ditengah era baru pilihan produk yang banyak tentu menjadikan konsumen kesulitan dalam memutuskan oleh sebab itu pemasar harus memikirkan cara paling mudah bagi konsumen untuk memutuskan. ikap empati di tempat kerja dapat berdampak positif terhadap kinerja bisnis, memotivasi karyawan, hingga meningkatkan produktivitas.

Itu berarti empati memegang peranan penting dalam dunia kerja. Memangnya, seberapa penting, bagaimana cara membangun sikap tersebut. Menciptakan hubungan harmonis dalam dunia kerja menjadi kunci sukses perusahaan untuk meningkatkan produktivitas. Sadar atau tidak, cara yang tepat untuk mewujudkan hal tersebut adalah sikap empati yang tinggi. Empati menjadi sikap yang perlu ditanamkan oleh karyawan jika ingin menciptakan lingkungan kerja yang positif. empati adalah kemampuan untuk memahami apa yang dirasakan oleh orang lain secara langsung.

Sering disangka sama, sebenarnya empati berbeda dengan simpati. Simpati cenderung dekat dengan merasa iba atau kasihan terhadap apa yang dialami oleh orang lain. Sementara itu, empati cenderung menempatkan diri pada posisi orang itu, dan ikut merasakan apa yang mereka rasakan. Ia mampu memahami diri sendiri dan orang lain, serta mampu memberikan respon yang tepat, dan berhubungan baik dengan orang-orang di sekitarnya.Itulah mengapa sikap empati penting untuk ditanamkan oleh para pekerja. Sebab, ketika memiliki rasa empati, maka otomatis kamu turut membangun hubungan yang harmonis di tempat kerja. Setelah mempelajari penjelasan di atas, kita tahu kalau empati adalah sikap dalam memahami perasaan orang lain dan turut serta untuk merasakan apa yang mereka rasakan. Nah, di atas juga sudah 
sempat disinggung kalau empati merupakan sikap yang harus ditanamkan oleh para pekerja demi menciptakan lingkungan yang nyaman.

Pasalnya, sesama karyawan sama-sama saling memotivasi dan tidak ada pikiran untuk menciptakan lingkungan yang toxic sehingga produktivitas pun kian meningkat. Alhasil, hal tersebut juga akan berdampak pada kesuksesan perusahaan dalam berbisnis karena karyawannya merasa bahagia dalam menyelesaikan pekerjaan. Bagi seorang individu yang baru bekerja, rasa empati diperlukan untuk menjaga hubungan dengan karyawan-karyawan lainnya. Sementara bagi pemimpin, empati juga penting untuk membuat bawahannya merasa lebih nyaman bekerja dengannya. Memiliki empati juga berarti membuat kita memperlakukan orang lain, sebagaimana kita ingin diperlakukan. Dengan begitu, empati adalah sikap yang akan membangun hubungan antar individu terjalin dengan harmonis. Untungnya, empati adalah sikap yang dapat dibangun oleh semua orang.Kamu dapat menanamkan sikap ini secara perlahan-lahan supaya dapat memahami orang lain dan membangun hubungan dengan mereka, khususnya dalam dunia kerja.

\section{Responsive}

Kecanggihan teknologi semakin membawa perubahan besar pada dunia UMKM yang mampu beradaptasi. Di kondisi seperti sekarang ini, memonitor usaha dilakukan para pelaku UMKM dengan bermodal internet dan smartphone. Mereka tak perlu repot ke toko atau tempat usaha untuk memonitor pelayanan pelanggan dan mengecek arus transaksi usaha. Itu karena semua dapat dilakukan online. Sama seperti namanya, responsiveness berkaitan langsung dengan ketanggapan. Artinya, responsiveness adalah tentang bagaimana perusahaan memberikan layanan yang responsif terhadap semua keinginan dan kebutuhan pelanggan. Biasanya responsiveness ini juga diikuti dengan penyampaian yang runtut namun tetap mudah dimengerti. yaitu kesadaran dan keinginan untuk membantu pelanggan dan memberikan jasa dengan cepat. Dimensi ini menekankan pada perhatian dan ketepatan ketika berurusan dengan permintaan, pertanyaan, dan keluhan pelanggan. Faktor pada variabel responsiveness yang dirasakan paling rendah oleh pelanggan ialah dalam hal "perhatian dari karyawan".

Perhatian yang ditunjukkan oleh karyawan tidak dirasakan oleh pelanggan, dimana karyawan hanya menjalankan Standar Operasi Perusahaan, hal memiliki penilaian paling rendah dari konsumen. Sedangkan faktor dari variabel assurance yang dirasa paling kurang oleh pelanggan ialah "karyawan dapat memberikan layanan dengan meyakinkan dan penuh kepercayaan diri" disini pelanggan kurang dapat diyakinkan oleh respon yang diberikan oleh para karyawan. Sedangkan faktor dari empathy yang dirasa paling kurang ialah dalam hal memahami apa yang menjadi kebutuhan dan keingainan dari konsumen. Kurang pahamnya karyawan akan apa yang menjadi kebutuhan dan keingingan dari konsumen membuat konsumen merasa kurang adanya perhatian dari pelanggan. Dalam pemasaran holistik jasa, pemasran diperankan bukan hanya oleh perusahaan terhadap pelanggan, akan tetapi juga dari para karyawan terhadap pelanggan; oleh karena itu disini karyawan memegang peran yang penting untuk dapat memberikan kepuasan pelanggan, apabila karyawan gagal memberikan pelayanan yang baik, maka memungkinkan untuk tidak terdapat pengaruh antara Dimensi responsiveness, assurance dan empathy terhadap kepuasan pelanggan.

Secara sederhana responsive logo merupakan bentuk minimalis dari sebuah logo perusahaan atau brand produk dan jasa namun tidak menghilangkan identitas khas dari brand tersebut. Kehadiran logo dalam versi responsif meningkat seiring dengan berkembangnya teknologi penggunaan berbagai media atau perangkat untuk mengakses situs suatu perusahaan. Jika dulunya mempertahankan desain logo original dengan banyak elemen yang diklaim pemilik usaha mencerminkan semua aspek perusahaan, seperti sejarah dan unsur lainnya. Maka ketika logo original dengan banyak elemen ini ditampilkan di perangkat digital, seperti PC, laptop, maupun smartphone. Tampilannya akan terkesan aneh dan berlebihan. Pasalnya ukuran atau luas dari perangkat akan mempengaruhi tampilan logo tersebut. Jika tidak responsif terhadap perubahan ukuran perangkat maka ada kemungkinan tampilan logo terpotong. Oleh sebab itu muncul konsep responsive yang menyediakan logo dalam versi minimalis, sehingga tampak menyeluruh saat dibuka di perangkat manapun. Arti Penting Logo yang Responsif untuk Branding. Adanya logo dalam kegiatan pemasaran atau promosi memiliki andil cukup besar, apalagi jika memakai versi responsif. Berikut adalah efek positif yang diciptakan dari penggunaan logo dalam versi responsif tersebut:

\section{PENUTUP}

\section{Simpulan}

Kegiatan yang dilaksanakan memberikan kontribusi pada peningkatan pengetahuan dan keterampilan. Salah satu manfaat dari kegiatan ini bisa berdampak pada perubahan metode pelaku Usaha UMKM yang mulai berfikir untuk terus 
beradaptasi dalam perubahan era saat ini dengan terus melakukan kegiatan pemasaran dengan cara baru salah satunya dengan media online yang mana semua anggota UMKM sudah mulai tergabung dengan pemasaran online salah satunya dengan media Instagram dimana para pelaku UMKM mulai memuat foto produk mereka untuk dapat dilihat konsumen lewat komunitas dan masyarakat umum yang lebih luas.

\section{Saran}

Sebagai saran, banyak saluran distribusi yang terbuka saat ini bisa digunakan para UMKM untuk memasarkan produk yang mereka hasilkan bukan hanya mengandalkan saluran offline saja yang memang masih memberikan hasil penjualan. Namun optimalisasi penjualan dengan manfaatkan media online juga perlu di coba bagi para pelaku UMKM agar memiliki jejaring pemasaran yang lebih luas.

\section{Ucapan Terima Kasih}

Demikianlah kegiatan Pengabdian Masyarakat ini dibuat, mudah-mudahan kegiatan ini bermanfaat terhadap para pelaku UMKM khususnya yang tergabung dalam Komunitas UMKM Naik Kelas. Atas perhatian dan kerjasama semua pihak yang turut serta membantu atas keberlangsungan acara ini, kami mengucapkan terima kasih.

\section{E. DAFTAR PUSTAKA}

Kartajaya, H., \& Marketeers, T. R. (2018). CITIZEN 4.0: Menjejakkan Prinsip-Prinsip Pemasaran Humanis di Era Digital. Gramedia Pustaka Utama.
Kotler, P., Kartajaya, H., \& Setiawan, I. (2019). Marketing 4.0: Moving From Traditional To Digital. In Gramedia. PT. Gramedia Pustaka Utama. https://doi.org/10.1142/9789813275478 0004

Suleman, D. (2018). Faktor Penentu Keputusan Konsumen Indonesia MemilihTempat Belanja Disebuah E-Commerce (Theory of Planned Behavior). Jurnal JDM, I(02), 1-9. http://journal.mercubuana.ac.id/index.php/jdm /article/view/4120

Suleman, D., Ali, H., Nusraningrum, D., \& Ali, M. M. (2020a). Consumer Behaviour in the Marketing 4.0 Era Regarding Decisions about Where to Shop. International Journal of Innovation, Creativity and Change, 13(7), Pp : 444-456.

https://www.ijicc.net/images/vol_13/Iss_7/13 763 Suleman_2020_E_R.pdf

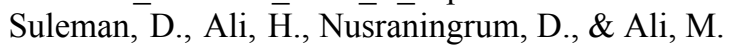
M. (2020b). Strategi memenangkan persaingan bisnis berbasis perilaku konsumen untuk produk fashion. Lembaga pendidikan dan pelatihan balai insan cendekia.

Suleman, D., Ali, H., Nusraningrum, D., \& Ali, M. M. A. (2019). Perceived Ease of Use, Trust and Risk toward Attitude and Intention in Shopping for Online Fashion Products In Indonesia. Archives of Business Research, Vol.7(No.4), pp.240-253. https://doi.org/DOI: http://dx.doi.org/10.14738/abr.74.2019

Suleman, D., Sabil, S., \& Suharyadi, D. (2021). Mengenali Perilaku Konsumen dan Konsep Strategi Pemasaran (berbasis teori dan pendekatan praktis). Insan Cendekia Mandiri.

Sumawan, U. (2002). Perilaku konsumen: Teori dan Penerapannya dalam Pemasaran. Pt. Ghalia Indonesia dengan MMA-IPB. 